\title{
Problem detection in legislative oversight: An analysis of legislative committee agendas in the U.K. and U.S.
}

\author{
Shaun Bevan (Shaun.Bevan@gmail.com ) \\ Department of Politics and International Relations, University of Edinburgh, UK \\ Will Jennings (w.j.jennings@ soton.ac.uk) \\ Department of Politics and International Relations, University of Southampton, UK \\ Mark Pickup (mark.pickup@gmail.com) \\ Department of Political Science, Simon Fraser University, Canada
}

WORD COUNT: 8,478 


\begin{abstract}
This paper outlines a dynamic problem-detection model of legislative oversight where legislative committees engage in information-gathering to identify emerging policy problems. It is argued that activities of legislative committees are responsive to indicators of problem status across a range of policy domains. This enables committees to react to problems before, or at least simultaneously to, citizens. Our analyses use a new dataset on the policy agenda of UK Parliamentary Select Committees in combination with directly comparable data on US Congressional hearings. Aggregate measures of problem status (e.g. GDP, crime rates) and public opinion on the 'most important problem' facing the country are used as independent variables. The comparison between a well-established and developing committee system offers insights into common dynamics across institutional contexts. The findings show that committee agendas in both the UK and US are responsive to problem status for the majority of issues.
\end{abstract}

Keywords: agenda-setting; congressional hearings; legislative oversight; problem detection; select committees 
How might legislative committees function as an early warning system for policy-makers in government, tracking the emergence of problems or issues on the agenda? Such committees are typically able to draw on research staff and policy expertise in a way that enables them to quickly identify issues that appear objectively to be getting worse (and to respond to the increased salience of those issues). This may be via the release of official statistics or via other signals, such as informal reports from the frontline of particular sectors - which could allow problems to be recognised before they even register with public opinion or become prominent in the media. ${ }^{1}$ Such committees also tend to be subject to fewer institutional or political constraints on the issues that can be selected for attention: it is possible for investigations to be instigated at the behest of small numbers of legislators with relevant authority and jurisdiction. Mechanisms of legislative oversight such as legislative committees, investigations and hearings are thus a crucial upstream channel of policy-making given their information-gathering and information-processing function.

In this paper, we offer the first cross-national test of a problem-detection model of legislative oversight agendas, building on research in the US (Adler and Wilkerson 2012; Workman 2015) and contributing to a growing comparative literature on agenda-setting dynamics across a range of political systems and institutional contexts (Baumgartner et al. 2006; 2011). The model suggests that legislative committees will respond directly to changes in the problem status of particular policy domains, or react indirectly by investigating issues that the public identifies as being (important) problems. We use a new dataset on the policy

\footnotetext{
${ }^{1}$ The time lag often involved in publication of official statistical estimates (e.g. economic or crime figures) makes it possible for legislative responses to occur before there has been a formal signal of the deterioration of conditions. Citizens also may, in the aggregate, recognise changes in objective conditions (e.g. prices) before there is a formal signal.
} 
agenda of Parliamentary Select Committees in the UK between 1997 and 2014 covering

8,381 reports of committee inquiries, coded according to the policy content coding scheme of the Comparative Agendas Project as well as data from the US Policy Agendas Project on Congressional committee hearings for the period 1956 to 2011. These oversight agendas are matched with measures of problem status and aggregate level survey data on the 'most important problem' (MIP) or 'most important issue' (MII). By estimating time series errorcorrection models using these data we find that committee attention to the majority of issue areas in both systems is responsive to problem status, above and beyond their responsiveness to public priorities.

\section{Legislative committees as detectors of problem signals}

Attending to problems is a fundamental dimension of politics and public policy (e.g. Cobb and Elder 1972; Jones and Baumgartner 2005; Adler and Wilkerson 2012; Workman 2015). At any point in time, lawmakers faced with abundant information and scarce resources must prioritise some problems while disregarding others. Political institutions are key to the processes by which attention is allocated to issues - structuring the distribution of policymaking time and resources at multiple levels across the political system (e.g. Baumgartner et al. 2009). Before attention can be allocated, however, information must be gathered and problems detected (Jones and Baumgartner 2005; Baumgartner and Jones 2015). Institutional designs and incentives (such as mechanisms of electoral sanction) structure the degree to which political actors are concerned with (proactive) information searches for policy problems in need of government action or with (reactive) representation of issues of public concern.

While legislative oversight can refer more narrowly to scrutiny of legislative proposals or investigation of the conduct of the executive, we define it more broadly as 
information-gathering, problem detection and agenda-setting by legislative committees. That is where committees monitor the activities and performance of government departments, identify and diagnose problematic areas of public policy, attend to areas of public concern, respond to major events or crises, and gather and assimilate evidence on issues that are currently on the decision-making agenda. Legislative oversight committees have many options open to them for attending to policy issues. They can initiate investigations and inquiries, hold hearings, compel witness testimony, undertake policy analyses, launch public consultations, and publish/promote findings and conclusions.

These legislative structures enable committee members to select issues for attention based on their own issue preferences, and signal to other political actors that certain issues are important and require attention. Oversight is therefore often interlinked with entrepreneurship by legislators and with the development of policy expertise within the legislature, enhancing the agenda-setting power of this institutional venue (King 1997; Baumgartner et al. 2000; Adler and Wilkerson 2012). Because of this, these legislative structures can function as an early warning system for policy-makers, undertaking continuous searches for salient information on emerging policy problems and in signalling those that require attention by decision-makers (Workman 2015). As a consequence, legislative oversight committees might be expected to perform an information-gathering and problem-detection function, searching for nascent policy problems and focusing political attention on them, in addition to reacting to issues currently of public concern. An alternative view of legislative oversight suggests that attention is subject to punctuated equilibrium, where there are extended periods of unresponsiveness before problems are addressed (Baumgartner and Jones 1993). This implies a lower, or more uneven, rate of responsiveness to the emergence policy problems.

Legislators' motivations to identify and respond to emerging policy problems are twofold; relating to either policy-seeking or vote-seeking goals. Firstly, committee members 
may be motivated by goals of 'good public policy' (Fenno 1973). As such, the identification and prioritisation of policy problems is also likely to influence their behaviour. Specifically, some legislators seek out membership on committees addressing pressing or controversial issues of national importance and therefore will subsequently look to investigate and attend to emerging policy problems. Secondly, there are prospective electoral consequences for committee members, and their parties, who fail or succeed to respond to problems that are of concern to the public. A substantial line of research on US Congressional committees has noted the re-election goals of committee members (see Fenno 1973; Mayhew 1974; Arnold 1990). Depending on the context, legislators may be concerned with responding to concerns of local or national electorates. While committee membership structures may diffuse any direct electoral benefits for individual legislators or parties for their oversight activities, reacting to problems that are of public concern may accrue policy entrepreneurs either individual benefits (in enhancing the personal reputation and influence of committee chairs and members) or indirectly secure collective benefits for one party or another (most typically for oppositions signalling failings of the incumbent). ${ }^{2}$

By considering these perspectives it is apparent that legislative oversight agendas may operate according to an information-gathering and problem-detection logic (Adler and Wilkerson 2012; Jones and Baumgartner 2015), whereby legislators' attention to issues

\footnotetext{
${ }^{2}$ The logics of problem detection operate in parallel to the public's attention to policy issues. Studies show that the public agenda tracks measures of problem status in some policy domains (Wlezien 2005). Therefore, public priorities provide legislators an additional warning of the existence of policy problems in a specific domain (i.e. policy-seeking), combined with a signal of a greater likelihood of political costs for inaction (i.e. voteseeking).
} 
precedes their prominence on the public agenda. This would make sense where legislators have access to private information from policy sectors (from industry, stakeholders or whistle blowers) or have expertise to interpret relevant, specialist information to identify problems.

Studies of congressional committees have tended to focus on the re-election goals of individual legislators and the oversight function of committees (Fenno 1973; Mayhew 1974). Agenda-setting theory highlights the link between agenda access and 'issue expansion' (Baumgartner and Jones 1991; also Cobb and Elder 1972), where policy change occurs through the mobilization of actors around an issue. According to this view, institutional venues are central to the identification of problems which give rise to pressure for policy change. Baumgartner and Jones (1991, p. 1051) argue that “... increasing attention is related to an increasingly negative policy image" whereby the undesirable aspects of policy (i.e. problem definition) leads to the mobilisation of political actors around an issue. What constitutes a problem is of course subject to social and political contestation (Cobb and Elder 1972; Baumgartner and Jones 1993), though legislators will often rely on policy indicators to tell them when things are going well or badly in a particular area.

The emergence of new issues and redefinition of old ones can lead to reorganisation of the focus and activities of legislative committees (King 1997; Baumgartner et al. 2000). Competition for jurisdiction over issues can be expressed through the allocation of legislative attention (e.g. hearings on a particular topic) to reflect the changing salience, and problem status of policy issues. Consequently, legislators are often concerned with detecting and highlighting routine problems and the early stages of crises or policy failures, to undertake oversight and/or push for policy change.

More generally, problem detection is a central function of government, linked to the expansion of policymaking activities (Baumgartner and Jones 2015). The information- 
gathering function of legislative committees is especially relevant for what McCubbins and Schwartz (1984) call 'police patrol' modes of oversight: centralised, active and direct attention to policy activities. Because the bulk of legislative hearings in the US draw on 'police patrol' oversight (Balla and Deering 2013), it might be expected that legislative committees will collectively tend to engage in information-gathering and problem-detection. This would contrast with 'fire alarm' modes of oversight, where problems are brought to the attention of legislators through the protestations of citizens and interest groups, and would imply a substantial lag in problem recognition.

Legislative oversight is organised both according to the preferences of legislators (Krehbiel 1990; King 1994) and the salience of issues (Baumgartner and Jones 1991; Talbert et al. 1995; Workman 2015). This suggests that legislative oversight is in part structured by issue salience; that is, via a process of problem-search which detects signals of policy problems by issue and prioritises problems for action (Baumgartner and Jones 2015). The substantial literature on the evolution of the US legislative committee system suggests that these dynamics of legislative attention are central to the ways in which legislators respond to the emergence of new issues and institutional competition for control over problem definition and issue expansion.

A similar set of preconditions for legislative oversight agendas exist in the UK, where the system of parliamentary select committees has evolved as a series of distinct issue jurisdictions since its creation in 1979 (Giddings 1994), and has become increasingly influential as a venue for scrutiny and agenda-setting (see Kelso 2016). Much less is known in the UK about the factors behind the evolution of the system of legislative jurisdiction and the degree to which it engages in information-gathering and problem-detection compared to the US. Both institutional systems share similar logics that are underpinned by the importance of problem-search and identification, expressed through the attention of committees to issues. 
If legislative committees are structures designed to search out salient information and give early warning of distant or fast-approaching tremors in public policy, it might be argued that these will tend to react before citizens are able to recognise that there is a problem and understand its magnitude. This is especially plausible in domains where there are high levels of technical complexity or tightknit policy communities of policy experts and organised interests. For legislators and committee staff with specialist expertise, it is likely that information signals about emerging problems will prompt oversight responses aimed at sounding the warning signal to the wider policy-making community and public.

Jones and Baumgartner (2005, p. 255) argue that because of the relatively 'upstream' nature of oversight in the policy process "it is reasonable to expect a reasonably rapid response in hearings activity to citizen concerns". While this means there is a low level of friction in selection of issues for the decision-making agenda, it is also possible that oversight committees are engaged in information searches for issues well before they become salient to the public or the media, via legislators with policy expertise and their professional staffs and networks, and through the processing of information from outside experts and organized interests within the relevant policy communities. Policy indicators also provide important signals of improvements or deteriorations of material conditions in particular domains. This problem-detection model of oversight suggests that legislative inquiries may lead, or respond at the same time as, public opinion. This informs the central hypothesis of this paper, that attention of legislative committees to policy domains reflect changes in indicators of the problem status of those domains:

H1: Oversight of policy domains by legislative committees directly responds to indicators of their problem status 
Our theory expects direct responsiveness of legislative oversight to problems. While voteseeking and policy-seeking goals of legislators are compatible with problem-detection, these do not necessarily imply a continuous process of adjustment in response to new information. Similarly, theories of disproportionate information processing imply an uneven pattern of responsiveness to problems, where problems are unattended to for extended periods of time (Jones and Baumgartner 2005). Our null hypothesis (H0) is, therefore, that oversight is not directly responsive to indicators of problem status.

Interestingly, while there is a substantial body of research on the representation of public opinion in Congress (see Brady 2011 for a review), there is little investigation of how public opinion influences Congressional oversight and investigation. Baumgartner and Jones' (1993) highlighted the role of public attention and issue definitions in leading to policy change, while Enns (2014) observes that increases in public punitiveness precede shifts in the attention of Congressional hearings to criminal justice issues.

Research shows that public attention to issues - typically measured with the "most important problem" survey question - tends to react to changes in problem status in particular domains (Wlezien 2005). Because of this, the issue concerns of the public offer decisionmakers an additional signal regarding the emergence of policy problems in a particular domain, or the existence of conditions that might give rise to a problem. These also can indicate the potential for political (electoral) costs of inaction by policymakers. As a consequence, it is important to allow for the possibility that legislative committees may adjust their oversight priorities to reflect public priorities.

\section{Data and Methods}


To test our problem-detection model we use a new comparative time series dataset on the policy agenda of legislative oversight committees, the problem status of issues and the issue priorities of the public in the US (1956 to 2011) and UK (1997 to 2014). These cases provide cross-national evidence from what might be considered the archetypal presidential and parliamentary (Westminster) systems - the US and the UK - and as such offer a test of the general structure of dynamics of legislative oversight agendas. The analyses presented here are based on aggregate-level time series data of legislative oversight agendas including US congressional hearings and published reports of select committees in the UK Parliament. This data is coded according to the policy content coding system of the Comparative Agendas Project (CAP, www.comparativeagendas.net), integrating data from the two countries. The advantages of this coding scheme are twofold: firstly, it is an established method for coding government and public attention and secondly it renders the content of agendas comparable across institutional venues, allowing us to model priorities of legislative committees and the public consistently over time.

\section{US Congressional Hearings}

Our measure of legislative oversight in the US is the number of congressional hearings by issue area by quarter. Oversight in the US primarily takes the form of congressional hearings where the viability and value of existing or possible future policy is judged. As a key committee tool and indicator of congressional attention, hearings take place at several stages of the policy-making process (see Baumgartner and Jones 1993). In order to focus our analyses on oversight we exclude all hearings that make a recommendation about a proposed bill, appropriation hearings, hearings that propose the creation of a new agency or program and hearings that consider legislation proposed by the president. This leads to a dataset consisting of the information-gathering activities of committees: measuring policy 
oversight and the early stages of congressional attention to new issues, but removing any legislative scrutiny of new legislation or budgeting processes. While not perfectly comparable to the UK data which is predominately oversight alone, both aspects of US hearings should respond to indicators of problem status in the same manner.

\section{UK Parliamentary Select Committee Reports}

Our measure of legislative oversight in the UK is the number of select committee reports by issue area in each quarter. In the UK, committee reports offer a visible and clear measure of attention within the parliamentary select committee system, indicating that an issue has been the subject of an institutional process of scrutiny. We have gathered and classified all of these reports from 1997 to 2012 in an original dataset. These reports represent the committees' assessment and/or recommendations based on the policy issue at hand. In the process leading to the publication of a report, the committee first selects an issue to attend to followed by a press notice with a call for written evidence. Anyone, including private individuals, businesses and other members of the government may submit evidence to the inquiry. Evidence is also required from the relevant government departments. The committee will then call a select group of interested parties and experts to give oral evidence. The committee further has the right to demand papers and records, as well as the participation of essential persons. While reports themselves are not binding for government, their cross-party nature, the requirement of a formal response from parliament and the higher than normal level of policy expertise means they are an important institutional device in the policy process (Hindmoor et al. 2009).

To measure the policy priorities of oversight agendas through the parliamentary select committee system, the summary and/or introduction of each report was coded according to the CAP coding system. Each committee report was manually blind-coded by two researchers 
at the major topic and sub-topic level, with an inter-coder reliability of $80 \%$ prior to thorough coding reconciliation. This generates a new and unique dataset on the policy agenda of the parliamentary select committee system.

\section{Public Priorities}

The issues priorities of the public are often measured with survey instruments that ask about the 'most important problem' or 'most important issue' facing the nation (Wlezien 2005; Jennings and Wlezien 2011). In the US, Gallup has regularly asked the MIP question since 1956, while in the UK Ipsos-MORI has fielded the MII question since 1977. We use aggregate responses to represent the broader public prioritization of issues at particular points in time, recoded to correspond to the CAP major topic codes.

\section{Measuring Problem Status}

The construction and contestation of 'problems' is at the heart of the study of agendasetting. At the same time, policy indicators provide important information about whether conditions in a particular area of economy or society have improved or deteriorated - and thus a relative signal of problem status (though not the way problems are framed). For example, the degree to which the economy is a problem can be measured according to the condition of an assortment of indicators of economic performance, such as unemployment, inflation and growth. Practically, identifying appropriate longitudinal measures of problem status is more difficult. Some issues, like the environment or government operations are so general that constructing a single meaningful measure of whether something is a problem is hard. For example, industrial pollution levels were at one time a good indicator of problem status of the environment, but since the 1990s carbon emissions and climate statistics have become increasingly relevant as benchmarks for measuring the problem status of the issue. 
However, clear measures of problem status with relevant quarterly data can be identified for four important policy issues in the US and six in the UK. These are listed in Table 1 (for more details see online Appendix A).

[Table 1]

Each measure corresponds to a key aspect of the problem status of each issue in as general a way as possible. Quarterly percentage growth in gross domestic product (GDP) indicates the overall state of the economy, specifically whether it is shrinking or growing, with high growth indicating lower problem status of the economy. The number of inward migrants measures the volume of immigration into the UK, typically viewed as a problem by an overwhelming majority of the public. Length of waiting times for operations in the National Health Service is another headline measure of performance, and therefore problem status, for the issue of healthcare in the UK, while the cost of healthcare is the most relevant measure in the US. While energy covers a broad range of policy concerns, domestic fuel costs are a good proxy for how problematic energy is for consumers. In transport, measures such as road-building and traffic are poor measures of the condition of national policy (and are often localised issues to some degree). In the US the price of gasoline is a strong indicator of the need for new transportation policy ${ }^{3}$, while in the UK the performance of train services provides an indication of the state of public transport, in a domain that government has often intervened in in the past. For criminal justice, measurement of the degree to which crime is a problem can be tricky, especially when perceptions of crime are at odds with official statistics. To capture the problem status of law and order in the UK, we use aggregate

\footnotetext{
${ }^{3}$ US gasoline prices and domestic fuel costs are highly correlated. However, they are not the same with fuel oil subject to more quarterly fluctuations due to demands based on weather.
} 
responses from the Crime Survey for England and Wales to the question "How safe do you feel walking along in this area after dark?" ${ }^{4}$ Here, higher values indicate greater concern about crime and therefore a greater problem status. ${ }^{5}$ A similar, quarterly measure in the US does not exist to our knowledge. The expected direction of the effect for each of these measures is presented in the final column of Table 1.

Topics

For this paper we specifically focus on six policy domains covered by CAP major topic codes. These correspond to the economy, civil rights and immigration, health, energy, transportation and law and order. Our decision to focus on these topic areas is determined by their status as major areas of public policy in the US and UK and the availability of appropriate indicators of problem status, which varies according to the policy domain.

In Figures 1 and 2 we present the frequency of hearings and reports on each of these issues each quarter for legislative oversight in the US and UK respectively.

[Figures 1 and 2]

\footnotetext{
${ }^{4}$ The correlation between fear of crime and a public priorities (MII) is quite low, 0.32, as crime can be downgraded as a priority as other issues become more important, even if the absolute level of concern with crime does not change.

${ }^{5}$ The survey also asks about individuals' actual experience of crime. Over the period between 2001 and 2012, the correlation of fear of crime and the rate of victimisation is equal to 0.83 $(P$-value $<0.0001)$. Alternative analyses with this measure did not change our substantive results.
} 
These Figures show it is quite rare for the amount of legislative oversight on a policy topic in a given quarter to be zero and when it is this is not due to recess periods. Secondly, the frequency of legislative oversight exhibits a substantial amount of variation. For example, in the UK (Figure 2) law and order is subject to two large spikes in oversight attention. The first, during the first quarter of 2005, primarily focused on prison reforms. The second, in the first quarter of 2010, was primarily focused on the effects of budget cuts on policing. For the US (Figure 1), there are distinct spikes in attention in energy during the 1970 s related to the oil crisis and in healthcare in the 1990s related to proposed, but failed, healthcare reforms.

\section{Analyses}

To test our hypothesis that legislative oversight agendas (AGENDA) respond to problem status (PROBLEM) controlling for public priorities (OPINION), a time series error correction model (ECM) is estimated for each topic:

$$
\begin{aligned}
\triangle \text { AGENDA }_{t}= & \alpha_{0}+\alpha_{1} \text { AGENDA }_{t-1}+\beta_{0} \Delta \text { PROBLEM } \\
& +\beta_{1} \text { PROBLEM }_{t-1} \\
& +\Delta \beta_{2} \text { OPINION }_{t}+\beta_{3} \text { OPINION }_{t-1}+\varepsilon_{t}
\end{aligned}
$$

This is the general form of the ECM and is appropriate for stationary data (Pickup 2015). It is consistent with the idea that legislative oversight agendas and problem status will coexist in a long-run equilibrium - where committees will respond both to short-term shocks and to divergence from that equilibrium state, as "too much" or "too little" attention is assigned to a particular policy problem (either overreacting or under-responding to the information signal). In the general ECM, the short-run (contemporaneous) effects of problem status and public priorities on legislative oversight $\left(\right.$ AGENDA $\left._{t}\right)$ are given by the coefficients on $\left(\triangle P R O B L E M_{t}\right)$ and $\left(\triangle \mathrm{OPINION}_{\mathrm{t}}\right)$ respectively. The long-run (lagged) effects of changes in 
problem status and public priorities can be calculated as $-\beta_{1} / \alpha_{1}$ and $-\beta_{3} / \alpha_{1}$ respectively. These are known as the long-run multipliers. The long-run effect can be interpreted as the cumulative effect that a one unit pulse (an increase for one period only) in the independent variable has on the dependent variable (in this case, number of reports/hearings) as the effect decays away. ${ }^{6}$ In supplementary analyses (see online Appendix B) we also consider the effects of divided government, as policy conflict can drive the size of oversight agendas (McGrath 2013). These produce substantively the same results as the models reported here.

It is also important to note that each of the US Congressional hearing series contain quarterly periodicity and quadratic trending, except for transportation which does not contain trending. Therefore, in the US error correction models, we include controls for quarterly periodicity and quadratic trending where necessary. ${ }^{7}$ Beyond these elements, the series are stationary. Controlling for the periodicity, we can reject the null hypothesis that the data is produced by a unit-root data generating process, against the alternative of a (trend) stationarity data generating process, for each series using the Dickey Fuller (DF) test. ${ }^{8}$ This is also true of the public priority variables, although we do not have a public priority measure for transportation as it has not historically been included as a category for Gallup's MIP

\footnotetext{
${ }^{6}$ It can also be interpreted as the full effect that a one unit increase in the independent variable has on the dependent variable if that one unit increase remains indefinitely. Of course, if the data is stationary, we do not expect the one-unit increase to remain indefinitely. ${ }^{7}$ As Congressional hearings may be less frequent in all areas in election (even-numbered) years, we also conduct a robustness test where we control for whether the hearings take place in an odd- or even-numbered year. The only issue area for which this control was significant was Health, for which its inclusion produced no substantive changes to the results.

${ }^{8}$ Congressional hearings test statistics: Economy, -9.229; Health, -7.024; Energy, -7.525; Transport, $-8.193 . P$-values $<0.001$.
} 
question in the US, most likely due to a low level of responses (as the salience of the issue is low with the public). ${ }^{9}$ Once we control for the periodicity, we can also reject the null hypothesis that the problem status data is produced by a unit-root data generating process. ${ }^{10}$

There is also evidence of periodicity in the UK select committee reports, except within the Economy reports. Controlling for periodicity when necessary, we can reject the null hypotheses that the reports data are produced by unit-root data generating processes (against the alternatives of a stationarity data generating process) for each issue area using the DF test. ${ }^{11}$ Also, once we control for periodicity, we can reject the null hypothesis that the problem status data for the UK are produced by unit-root processes ${ }^{12}$ and the null hypothesis that the public priorities data are produced by unit root processes. ${ }^{13}$

To allow for the possibility of trending and quarterly periodicity, we include these controls in the error correction models. To save space, we have reported the results without.

[Table 2 and 3]

${ }^{9}$ DF test statistics for MII: Economy, -2.829; Health, -3.278; Energy, -6.391. $P$-values $<0.05$.

${ }^{10}$ Test statistics for Problem status: Economy, -44.601; Health, -0.567; Energy, -1.971; Transport, $-3.059 . P$-values $<0.05$.

${ }^{11}$ Test statistics for Committee reports: Economy, -6.048; Civil, -5.857; Health, -6.651; Energy, -6.645; Transport, -6.157; Law, -5.998. $P$-values $<0.001$.

${ }^{12}$ Test statistics for Problem status: Economy, -4.047; Civil, -2.322; Health, -3.4337; Energy, -1.735; Transport, -2.623; Law, -2.830. $P$-values $<0.05$.

${ }^{13}$ Test statistics for MII: Economy, -4.040; Civil, -2.024; Health, -2.493; Energy, -4.460; Transport, -3.794; Law, -2.742. $P$-values $<0.05$. Note that the test for the economy (as the most important issue) includes a control for a structural break in the second quarter of 2008. 
The results for this analysis on US congressional hearings are reported in Tables 2 and 3 (long-run effects). For each model, we are unable to reject the null hypothesis that the errors do not contain first-order serial correlation, using the Breusch Godfrey test. ${ }^{14}$ The findings offer clear support for our theoretical expectations concerning problem status $(\mathrm{H} 1)$ and weaker evidence of an effect for public priorities. For every issue we see a positive and significant effect for our measures of problem status in either the short and/or long-run. In two issue areas, the economy and energy there is also a clear effect for public priorities on the congressional oversight agenda with a positive and significant effect in the short and/or longrun. Combined, these results offer clear evidence that problem status, and to a lesser extent public priorities, play an important part in congressional oversight.

It is helpful to consider some examples of the substantive effect of changes in our independent variables on our dependent variable, the number of congressional hearings. In the case of energy, in Table 3, a positive and statistically significant long-run effect, equal to 0.036, indicates that a one dollar increase in the per barrel price of domestic fuel oil leads, on average, to 0.036 more congressional hearings on energy in the long-run. The standard deviation for the price of fuel oil is $\$ 39$, so a typical effect in a given quarter is about 1.4 more (or less) hearings. In the case of health, the statistically significant short-run effect of 2.02 for average medical care costs in Table 2 indicates that a one dollar increase in average medical care costs (per member of the public) leads to 2.02 more congressional hearings on health in the short-run. The standard deviation for average per person medical care costs is $\$ 5.6$, so a typical effect in a given quarter is many times larger (11.31 additional hearings). We can compare these effects to those of public priorities. The average effect of public opinion (that is, the effect of a one standard deviation increase or decrease in the issue as a

${ }^{14}$ Test statistics: Economy, 0.255; Health, 0.001; Energy, 0.361; Transport, 0.8034. P-values $<0.05$ 
priority) is an additional 2.44 hearings in the long run for energy, and an additional 1.42 additional hearings in the long run for the economy.

[Tables 4 and 5]

The results for the analysis on UK select committee reports are reported in Tables 4 and 5 (long-run effects). For each model, except one, we are unable to reject the null hypothesis that the errors do not contain first-order serial correlation, using the Breusch Godfrey test. The exception was the model for energy. To account for the additional dynamics, we included a lag of the first difference of energy problem status and of energy as a public priority. Once this was done, we could not reject the null hypothesis that the errors do not contain serial correlation. ${ }^{15}$

The model estimates further support our theoretical expectations concerning problem status (H1), but demonstrate no discernible effect for public priorities. Across all issues there are no observed short- or long-run effects of public priorities on the legislative oversight agenda, with the exception of energy for which there is a negative long-run effect. In contrast, in three of the six models the problem status of the domain is a significant predictor of legislative oversight, in either the short- or the long-run. This finding applies to the economy, civil rights (immigration), and energy. Again, it is helpful to consider some examples of the substantive effect of changes in our independent variables on the number of committee reports. In the case of the economy, in Table 5, a negative and significant long-run effect, equal to -1.31 , indicates that a one-point increase in quarterly GDP growth leads, on average, to 1.31 fewer reports on the economy in the long-run. The standard deviation of the GDP

\footnotetext{
${ }^{15}$ Breusch Godfrey test statistics: Economy, 0.126; Civil: 0.018; Health, 0.257; Energy, 0.359; Transport, 0.179; Law, 0.800. The $P$-value for each is greater than 0.05 .
} 
growth variable is 0.75 so this is a bit larger than the typical effect in a given quarter. In the case of energy, the sum of the coefficients on the first difference and the lag of the first difference in the consumer price index for domestic fuels in Table 4 is 0.37 . This indicates that an increase of one in the 0 to 100 price index leads to 0.37 more reports on energy by the following quarter. The standard deviation for the fuel price index variable is 22.4 , so the potential effects are much larger, with an average effect of 8.3 more or less reports.

\section{Conclusion}

The capacity of legislative committees to detect when things are going wrong in particular policy areas is an important indicator of the quality of democratic government. Such legislative committees possess resources and policy expertise that equip them to identify issues of social and economic concern, and are not subject to the same degree of institutional or political constraints (or 'friction') as other venues. In comparative perspective their relative sensitivity in the detection of problems, and responsiveness to the concerns of citizens, may tell us something about how different legislative systems simultaneously react to policy problems.

In this study we have offered a cross-national test of the responsiveness of the policy agenda of legislative committees to measures of problem status, the problem-detection model of legislative oversight. Our theory argued that legislative committees can either respond to issues of public concern or identify and investigate emerging policy problems and signal their salience to other political actors, the media and the public. We specifically tested whether the policy agenda of legislative committees in the US and UK are responsive to changes in the problem status of policy issues controlling for the issue priorities of the public. The analysis was based on a new comparative dataset of the reports of parliamentary select committees for 
the UK, US Congressional hearings and measures of problem status and public priorities in both countries.

Legislative oversight does indeed appear to act as an early warning system for policymakers in detecting problems. Our results indicate clear support for the problem-detection model for a number of policy domains in the US and the UK, in that problem status is a significant predictor of legislative oversight in four out of four issues in the US and three of six in the UK. Changes in social and economic conditions impact on the issue agenda of legislative committees, suggesting policy-makers are attentive to signals of problem status. There is some variety in the presence of short- and long-run effects, suggesting that in some cases legislators react to signals of change, while in others the level of problem status is the source of a response. There is also some evidence that the oversight agenda is responsive to public opinion, but for fewer issues, with positive and significant effects for public priorities on committee hearings in the US for the economy and energy. This is interesting as it implies that the US legislative system is more opinion-responsive than the UK although this could be due to the US data covering an earlier phase of the policy process which has been shown to be more responsive (Bevan and Jennings 2014). Citizens therefore have an important role to play in shaping the problem detection activities of legislators. Nevertheless, it appears that legislative oversight is structured by the salience of policy problems even controlling for the degree to which those problems are identified in public priorities. While no doubt a great deal of information affects the conclusions of legislative committees given their design and calls for public comment, it seems as if the decision to hold a hearing or produce a report is largely driven by indicators of problem status.

Our conclusions come with two important caveats. Firstly, they are based on findings for a limited number of policy areas with visible indicators. While major policy issues, these are just some of the many issues that governments deal with. Further research into policies 
with less readily available indicators is required. Secondly, while measures like economic growth, hospital waiting times and healthcare costs are commonly accepted measures of performance, and therefore problem status, whether these are informative about the framing of a particular policy issue is a more complicated question. That is outside the scope of this study, but raises important questions regarding how performance measures relate to problemframing and construction.

Our study has provided specific insights on the functioning of legislative committee systems in the US and UK, but also raises questions for the comparative study of agendasetting and legislative oversight. What variation might be expected in responsiveness of legislative committees to problem signals across political systems? For example, might committees be quicker to recognise emerging policy problems where legislators have more formal and informal influence and where committees are subject to greater competition over jurisdiction of their activities? Might the institutional maturity of legislative committee systems influence their democratic responsiveness? We have provided evidence of a problem-detection function of legislative oversight across very different legislative systems, but institutional variation surely would be expected as a function of the responsibilities and incentives of legislators. Our analysis offers a first step in understanding the agenda-setting dynamics of legislative oversight in comparative perspective. 


\section{References}

Adler, E. Scott, and John D. Wilkerson. (2012). Congress and the Politics of Problem Solving. Cambridge: Cambridge University Press.

Arnold, R. Douglas. (1990). The Logic of Congressional Action. New Haven, CT: Yale University Press.

Balla, Steven J. and Christopher J. Deering. (2013). 'Police Patrol and Fire Alarms: An Empirical Examination of the Legislative Preference for Oversight.' Congress \& the Presidency 40(1): 27-40.

Baumgartner, Frank R., Christian Breunig, Christoffer Green-Pedersen, Bryan D. Jones, Peter B. Mortensen, Michiel Nuytemans, and Stefaan Walgrave. (2009). 'Punctuated Equilibrium in Comparative Perspective.' American Journal of Political Science 53(3): 602-619.

Baumgartner, Frank R., Christoffer Green-Pedersen, and Bryan D. Jones. (2006).

'Comparative Studies of Policy Agendas.' Journal of European Public Policy 13(7): 955-970.

Baumgartner, Frank R. and Bryan Jones. (1991). 'Agenda Dynamics and Policy Subsystems.' Journal of Politics 53(4): 1044-1074.

Baumgartner, Frank R. and Bryan Jones. (1993). Agendas and Instability in American Politics. Chicago: University of Chicago Press.

Baumgartner, Frank R. and Bryan D. Jones. (2015). The Politics of Information: Problem Definition and the Course of Public Policy in America. Chicago: University of Chicago Press.

Baumgartner, Frank R., Bryan D. Jones and Michael C. MacLeod. (2000). 'The Evolution of Legislative Jurisdictions.' Journal of Politics 62(2): 321-349. 
Baumgartner, Frank R., Bryan D. Jones and John Wilkerson. (2011). 'Comparative Studies of Policy Dynamics.' Comparative Political Studies 44(8): 947-972.

Bevan, Shaun and Will Jennings. (2014). 'Representation, Agendas and Institutions.' European Journal of Political Research 53(1): 37-56.

Brady, David W. (2011). 'Public Opinion and Congressional Policy.' In George C. Edwards, Frances E. Lee, and Eric Schickler (eds.) The Oxford Handbook of the American Congress. Oxford: Oxford University Press.

Cobb, Roger W., and Charles Elder. (1972). Participation in American politics: the dynamics of agenda-building. Baltimore: Johns Hopkins University Press

Enns, Peter. (2014). 'The Public's Increasing Punitiveness and Its Influence on Mass Incarceration in the United States.' American Journal of Political Science 58(4): 857872.

Fenno, Richard F. (1973). Congressmen in Committees. Boston: Little, Brown.

Giddings, Philip. (1994). 'Select Committees and Parliamentary Scrutiny: Plus Ça Change.' Parliamentary Affairs 47(4): 669-686.

Jennings, Will, and Christopher Wlezien. (2011). 'Distinguishing between Most Important Problems and Issues?' Public Opinion Quarterly 75(3): 545-555.

Jones, Bryan D., and Frank R. Baumgartner. (2005). The Politics of Attention: How Government Prioritizes Problems. Chicago: University of Chicago Press.

Kelso, Alexandra. (2016). 'Political leadership in Parliament: the role of select committee chairs in the UK House of Commons.' Politics and Governance 4(2): 115-126.

King, David C. (1997). Turf Wars: How Congressional Committees Claim Jurisdiction. Chicago: Chicago University Press.

Krehbiel, Keith. (1990). ‘Are Congressional Committees Composed of Preference Outliers?' American Political Science Review 84(1): 149-163. 
Mayhew, David R. (1974). Congress: The Electoral Connection. New Haven: Yale University Press.

McCubbins, Mathew D., and Thomas Schwartz. (1984). 'Congressional Oversight Overlooked: Police Patrols versus Fire Alarms.' American Journal of Political Science 28(1): 165-179.

McGrath, Robert J. (2013). 'Congressional Oversight Hearings and Policy Control.' Legislative Studies Quarterly 38(3): 349-376

Pickup, Mark. (2015). Introduction to Time Series Analysis. Thousand Oaks: Sage.

Talbert, Jeffrey C., Bryan D. Jones and Frank R. Baumgartner. (1995). 'Nonlegislative Hearings and Policy Change in Congress.' American Journal of Political Science 39(2): 383-405.

Wlezien, Christopher. (2005). 'On the Salience of Political Issues: The problem with 'most important problem.' Electoral Studies 24(4): 555-79.

Workman, Sam. (2015). The Dynamics of Bureaucracy in the US Government: How Congress and Federal Agencies Process Information and Solve Problems. Cambridge: Cambridge University Press. 
Figure 1: Congressional Hearings by Major Topic, 1956 to 2011
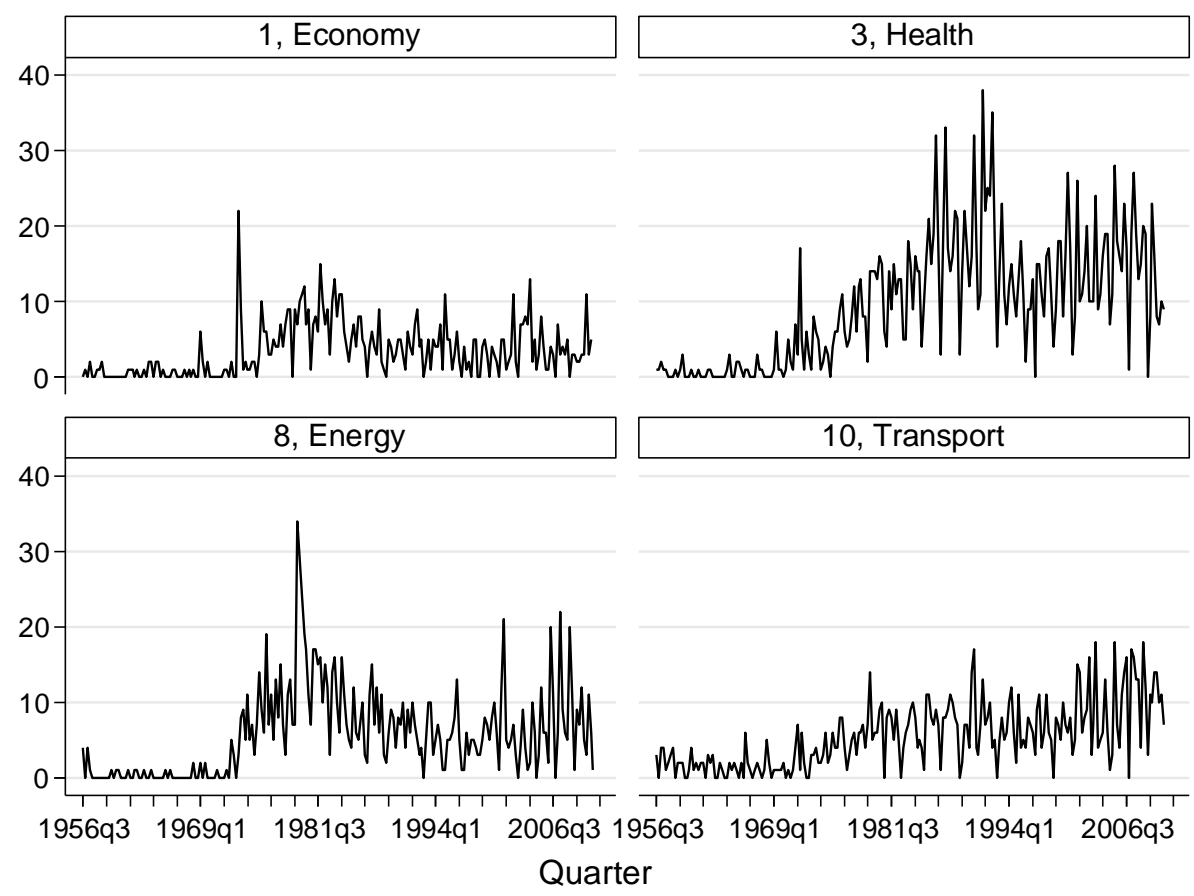

Figure 2: Select Committee Reports by Major Topic, 1997-2013




Table 1: Measures of Problem Status by Issue

\begin{tabular}{lllc}
\hline Topic & Measure & Abbreviation & Expected Direction \\
\hline \multicolumn{1}{c}{ US } & & & \\
\hline 1, Economy & Gross Domestic Product Growth & Growth & - \\
3. Health & Average Medical Care Cost & Medical & + \\
8, Energy & Domestic Fuel Oil Prices & Fuel & + \\
10, Transport & Domestic Gas Prices & Gas & + \\
\hline \multicolumn{1}{c}{ UK } & & & - \\
\hline 1, Economy & Gross Domestic Product Growth & Growth & + \\
2, Civil & Immigration Inflows & Immigration & + \\
3, Health & NHS Median Waiting Time & NHS_Wait & + \\
8, Energy & Domestic Fuel Oil Prices & Fuel & - \\
10, Transport & Railroad Public Performance Measure & Rail_PPM & + \\
12, Law & Mean response to "How safe do you feel & Safety & \\
& walking along in this area after dark?" & & \\
\hline
\end{tabular}

Table 2: The Effects of Public Priorities and Problem Status on Congressional Hearings

\begin{tabular}{|c|c|c|c|c|}
\hline & Economy & Health & Energy & Transport \\
\hline Hearings $_{\mathrm{t}-1}$ & $\begin{array}{l}-0.74 \\
(0.07) * * *\end{array}$ & $\begin{array}{l}-0.72 \\
(0.07) * * *\end{array}$ & $\begin{array}{l}-0.67 \\
(0.07) * * *\end{array}$ & $\begin{array}{l}-1.01 \\
(0.099) * * *\end{array}$ \\
\hline$\Delta \mathrm{MIP}_{\mathrm{t}}$ & $\begin{array}{c}3.81 \\
(2.71)\end{array}$ & $\begin{array}{c}1.15 \\
(12.10)\end{array}$ & $\begin{array}{l}45.12 \\
(7.06) * * *\end{array}$ & \\
\hline $\mathrm{MIP}_{\mathrm{t}-1}$ & $\begin{array}{l}5.61 \\
(1.29)^{* * *}\end{array}$ & $\begin{array}{c}8.06 \\
(7.01)\end{array}$ & $\begin{array}{l}33.36 \\
(6.64)^{* * *}\end{array}$ & \\
\hline$\Delta$ Growth $_{\mathrm{t}}$ & $\begin{array}{r}-17.18 \\
(8.65) *\end{array}$ & & & \\
\hline Growth $_{\mathrm{t}-1}$ & $\begin{array}{l}-14.91 \\
(16.28)\end{array}$ & & & \\
\hline$\Delta$ Medical $_{t}$ & & $\begin{array}{l}2.02 \\
(0.60)^{* * *}\end{array}$ & & \\
\hline Medical $_{\mathrm{t}-1}$ & & $\begin{array}{l}-0.04 \\
(0.07)\end{array}$ & & \\
\hline$\Delta$ Fuel $_{t}$ & & & $\begin{array}{c}0.04 \\
(0.02)\end{array}$ & \\
\hline Fuel $_{t-1}$ & & & $\begin{array}{l}0.02 \\
(0.01) * *\end{array}$ & \\
\hline$\Delta \mathrm{Gas}_{\mathrm{t}}$ & & & & $\begin{array}{l}4.09 \\
(1.77)^{*}\end{array}$ \\
\hline $\mathrm{Gas}_{\mathrm{t}-1}$ & & & & $\begin{array}{l}2.48 \\
(0.65)^{* * *}\end{array}$ \\
\hline Constant & $\begin{array}{l}-0.71 \\
(0.47)\end{array}$ & $\begin{array}{l}-0.36 \\
(1.43)\end{array}$ & $\begin{array}{l}-0.92 \\
(0.59)\end{array}$ & $\begin{array}{l}5.07 \\
(0.89) * * *\end{array}$ \\
\hline$R^{2}$ & 0.50 & 0.58 & 0.56 & 0.63 \\
\hline$N$ & 216 & 216 & 217 & 110 \\
\hline
\end{tabular}

Table 3: Long Run Effects of Public Priorities and Problem Status on Congressional Hearings

\begin{tabular}{lllll}
\hline & Economy & Health & Energy & Transport \\
\hline LR MIP & 7.54 & 11.25 & 49.69 & NA \\
& $(1.58)^{* * *}$ & $(9.76)$ & $(8.70)^{* * *}$ & \\
LR Problem & -20.05 & -0.049 & 0.036 & 2.45 \\
& $(21.77)$ & $(0.096)$ & $(0.012) * *$ & $(0.58) * * *$ \\
\hline
\end{tabular}


Table 4: The Effects of Public Priorities and Problem Status on Select Committee Reports

\begin{tabular}{|c|c|c|c|c|c|c|}
\hline & Economy & Civil & Health & Energy & Transport & Law \\
\hline Reports $_{\mathrm{t}-1}$ & $\begin{array}{l}-0.81 \\
(0.13) * * *\end{array}$ & $\begin{array}{l}-1.03 \\
(0.18)^{* * *}\end{array}$ & $\begin{array}{l}-1.02 \\
(0.17)^{* * *}\end{array}$ & $\begin{array}{l}-1.10 \\
(0.12)^{* * *}\end{array}$ & $\begin{array}{l}-0.83 \\
(0.13) * * *\end{array}$ & $\begin{array}{l}-0.91 \\
(0.17)^{* * *}\end{array}$ \\
\hline$\Delta \mathrm{MII}_{\mathrm{t}}$ & $\begin{array}{l}-0.04 \\
(0.06)\end{array}$ & $\begin{array}{l}-0.04 \\
(0.12)\end{array}$ & $\begin{array}{l}-0.01 \\
(0.09)\end{array}$ & $\begin{array}{l}-0.42 \\
(0.23)\end{array}$ & $\begin{array}{c}0.92 \\
(1.05)\end{array}$ & $\begin{array}{c}0.28 \\
(0.24)\end{array}$ \\
\hline$\Delta \mathrm{MII}_{\mathrm{t}-1}$ & & & & $\begin{array}{c}0.09 \\
(0.23)\end{array}$ & & \\
\hline $\mathrm{MII}_{\mathrm{t}-1}$ & $\begin{array}{l}-0.03 \\
(0.02)\end{array}$ & $\begin{array}{l}-0.05 \\
(0.10)\end{array}$ & $\begin{array}{c}0.07 \\
(0.09)\end{array}$ & $\begin{array}{l}-0.69 \\
(0.26)^{* *}\end{array}$ & $\begin{array}{l}-0.63 \\
(1.23)\end{array}$ & $\begin{array}{c}0.16 \\
(0.16)\end{array}$ \\
\hline$\Delta$ Growth $_{\mathrm{t}}$ & $\begin{array}{l}-0.89 \\
(0.52)\end{array}$ & & & & & \\
\hline Growth $_{\mathrm{t}-1}$ & $\begin{array}{l}-1.06 \\
(0.47)^{*}\end{array}$ & & & & & \\
\hline$\Delta$ Immigration $_{\mathrm{t}}$ & & $\begin{array}{c}0.04 \\
(0.03)\end{array}$ & & & & \\
\hline Immigration $_{\mathrm{t}-1}$ & & $\begin{array}{c}0.02 \\
(0.01)^{*}\end{array}$ & & & & \\
\hline$\Delta \mathrm{NHS}_{-} \mathrm{Wait}_{\mathrm{t}}$ & & & $\begin{array}{c}0.77 \\
(1.53)\end{array}$ & & & \\
\hline NHS_Wait ${ }_{t-1}$ & & & $\begin{array}{l}-0.18 \\
(0.70)\end{array}$ & & & \\
\hline$\Delta$ Fuel $_{t}$ & & & & $\begin{array}{c}0.05 \\
(0.08)\end{array}$ & & \\
\hline$\Delta$ Fuel $_{t-1}$ & & & & $\begin{array}{l}0.32 \\
(0.08) * * *\end{array}$ & & \\
\hline Fuel $_{t-1}$ & & & & $\begin{array}{c}0.00 \\
(0.01)\end{array}$ & & \\
\hline$\Delta$ Rail_PPM ${ }_{t}$ & & & & & $\begin{array}{c}0.04 \\
(0.20)\end{array}$ & \\
\hline Rail_PPM ${ }_{t-1}$ & & & & & $\begin{array}{l}-0.07 \\
(0.14)\end{array}$ & \\
\hline$\Delta$ Safety $_{\mathrm{t}}$ & & & & & & $\begin{array}{l}-60.54 \\
(37.51)\end{array}$ \\
\hline Safetyt-1 & & & & & & $\begin{array}{c}-13.12 \\
(9.15)\end{array}$ \\
\hline Constant & $\begin{array}{l}3.84 \\
(0.81)^{* * *}\end{array}$ & $\begin{array}{l}-4.42 \\
(3.54)\end{array}$ & $\begin{array}{c}-697.78 \\
(1,709.45)\end{array}$ & $\begin{array}{l}2.85 \\
(0.77)^{* * *}\end{array}$ & $\begin{array}{c}11.45 \\
(13.21)\end{array}$ & $\begin{array}{c}33.13 \\
(19.55)\end{array}$ \\
\hline$R^{2}$ & 0.44 & 0.69 & 0.68 & 0.64 & 0.46 & 0.68 \\
\hline$N$ & 68 & 39 & 47 & 67 & 67 & 44 \\
\hline
\end{tabular}

$* p<0.05 ; * * p<0.01 ; * * * p<0.001$

Note: models include controls for quarterly periodicity and trending

Table 5: Long Run Effects of Public Priorities and Problem Status on Select Committee Reports

\begin{tabular}{lllllll}
\hline & Economy & Civil & Health & Energy & Transport & Law \\
\hline LR MII & -0.03 & -0.05 & 0.06 & -0.623 & -0.77 & 0.18 \\
& $(0.02)$ & $(0.10)$ & $(0.08)$ & $(0.23)^{*}$ & $(1.50)$ & $(0.17)$ \\
LR Problem & -1.31 & 0.02 & -0.22 & .0017 & -0.08 & -14.48 \\
& $(0.58)^{*}$ & $(0.01)^{*}$ & $(0.17)$ & $(.008)$ & $(0.18)$ & $(9.52)$ \\
\hline
\end{tabular}

$* \mathrm{p}<0.05 ; * * \mathrm{p}<0.01 ; * * * \mathrm{p}<0.001$ 
ONLINE APPENDIX A: Problem Status Measures

Measures of problem status were gathered from official government sources and chosen based on their availability over time as quarterly data. In most cases only a single series was found that could be easily and directly tied to each issue area. GDP growth is the clear exception where other measures of economic performance such as inflation and unemployment are easily obtainable. However, given that these alternative measures are often tied to particular parts of society and even the interests of certain political parties we chose to use GDP growth.

\section{$\underline{\text { United States }}$}

Table A1 lists all measures of problem status we use for the US.

Table A1: US Measures of Problem Status

\begin{tabular}{ll}
\hline Measure & Source \\
\hline Gross Domestic Product Growth & $\begin{array}{l}\text { Gross domestic product (billions \$) (Bureau of } \\
\text { Economic Analysis). }\end{array}$ \\
Average Medical Care Cost & $\begin{array}{l}\text { Consumer price index: medical care services (\$) } \\
\text { (Bureau for Labor Statistics, CUSR0000SAM2). }\end{array}$ \\
Domestic Fuel Oil Prices & $\begin{array}{l}\text { Consumer price index: Domestic fuel oil per 100 } \\
\text { gallon barrel (\$) (Bureau for Labor Statistics). }\end{array}$ \\
& $\begin{array}{l}\text { U.S. Total Gasoline Through Company Outlets } \\
\text { Price by All Sellers (\$ per Gallon) (US Energy } \\
\text { Information Administration) }\end{array}$ \\
\hline
\end{tabular}

With the exception of GDP growth and Domestic Gas Prices, all US data was gathered from historical trends series available through the Bureau of Labor Statistics (BLS; see http://www.bls.gov/data/). This data was seasonally adjusted in real dollar terms based on 
urban averages for medical care services, a 100 gallon barrel of domestic fuel oil and a gallon of gasoline (averaged across all octanes).

GDP growth was calculated using seasonally adjusted data from the Bureau of Economic Analysis (BEA; see http://www.bea.gov/). This was used as the BEA offered a more user friendly version of the dataset. Domestic gas prices was obtained through the US energy information and ministration website

(https://www.eia.gov/dnav/pet/pet pri allmg a EPM0 PTC Dpgal m.htm). Regardless, all data sources are based on official government statistics. Figure A1 presents each of these series over time.

Figure A1: US Problem Status Measures Over Time
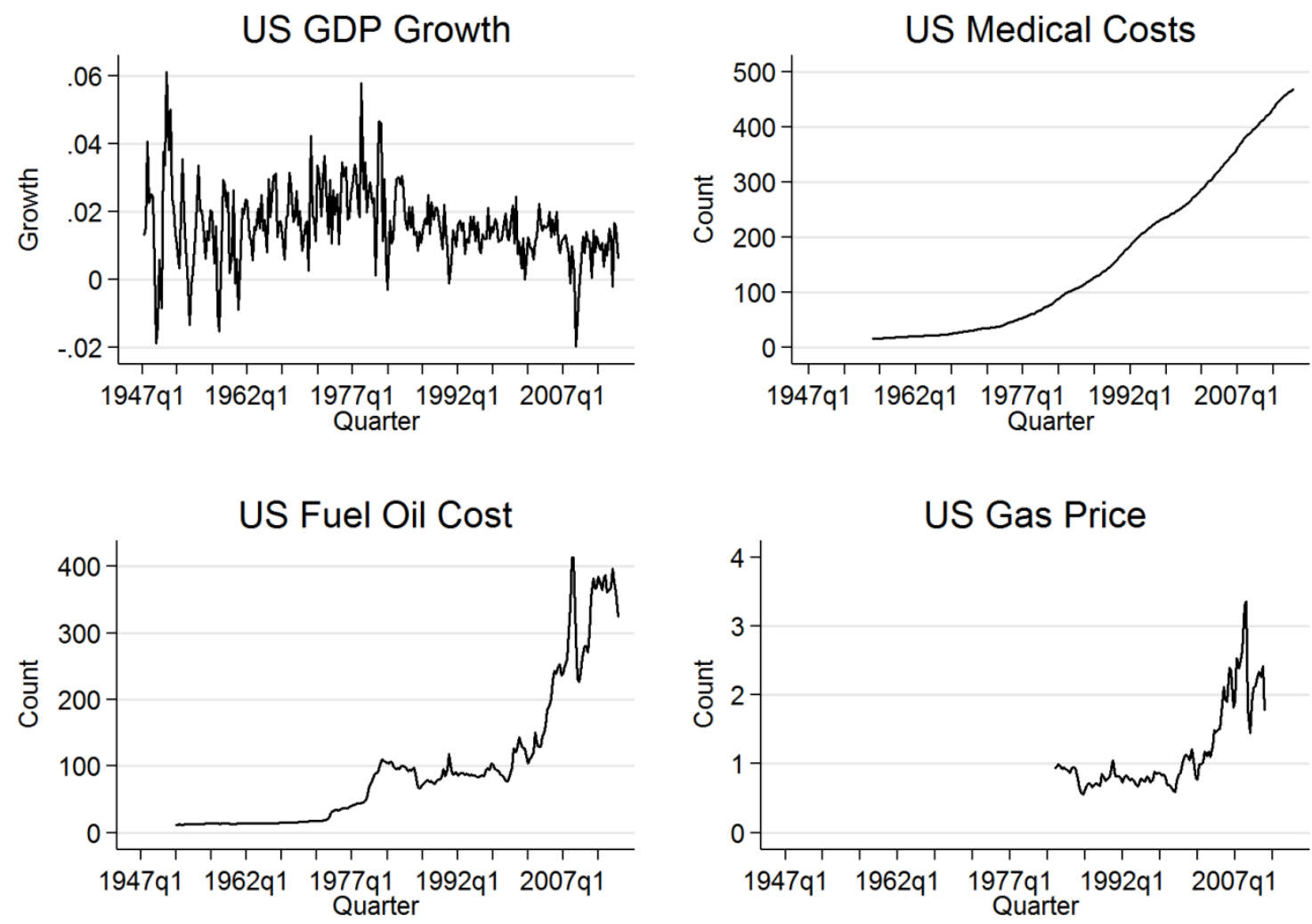


\section{United Kingdom}

Table A2 lists the measures of problem status for the UK.

Table A2: UK Measures of Problem Status

\begin{tabular}{|c|c|}
\hline Measure & Source \\
\hline Gross Domestic Product Growth & $\begin{array}{l}\text { Gross domestic product (quarter-on-quarter } \\
\text { growth: chained values, seasonally adjusted, } \\
\text { percentage) (ONS, IHYQ). }\end{array}$ \\
\hline Immigration inflows & $\begin{array}{l}\text { Long-Term International Migration, Rolling } \\
\text { annual data to year ending December } 2012 \text { (OFS, } \\
\text { International Passenger Survey). }\end{array}$ \\
\hline $\begin{array}{l}\text { National Health Service median } \\
\text { waiting time }\end{array}$ & Median waiting time: (Department of Health). \\
\hline Domestic Fuel Oil Prices & $\begin{array}{l}\text { Consumer price index: domestic fuels (fuel price } \\
\text { index numbers relative to the GDP deflator, } \\
\text { base }=100 \text {, April 2010) (ONS). }\end{array}$ \\
\hline Railroad Public Performance Measure & $\begin{array}{l}\text { Public performance measure: all operators (Office } \\
\text { of Rail Regulation). }\end{array}$ \\
\hline Fear of crime & $\begin{array}{l}\text { British Crime Survey: mean response to survey } \\
\text { question "How safe do you feel walking along in } \\
\text { this area after dark?" (Farrall et al. Long-Term } \\
\text { Trajectories of Crime in the United Kingdom, } \\
\text { 1982-2013. [data collection]. UK Data Service. } \\
\text { SN: 7875, http://dx.doi.org/10.5255/UKDA-SN- } \\
7875-1 \text { ). }\end{array}$ \\
\hline
\end{tabular}

The UK data was collected from various government sources. GDP growth is the percentage quarter-on-quarter growth (using chained, seasonally adjusted values of GDP). Immigration inflows represent a rolling count of the number of immigrants entering and staying in the country in thousands over the course of the calendar year. ${ }^{16}$ Median waiting time for NHS appointments in days is used as our measure of healthcare problem status. Domestic fuel oil prices fuel price index numbers relative to the GDP deflator represent energy, mostly home heating costs. Customer satisfaction with rail performance is used to measure the problem status of transport in the UK where a substantial portion of the public commute using public

\footnotetext{
${ }^{16}$ Note this is different than net immigration as it does not account for the number of international and UK citizens emigrating from the UK.
} 
transport and this is a major focus of public policy. Finally, for the problem status of law and order, we aggregate responses to the survey question "How safe do you feel walking along in this area after dark?" based on data from the British Crime Survey (which later became the Crime Survey for England and Wales). This data is coded so that high numbers relate to more aggregate concern over crime and logically higher problem status. Figure A2 presents each of these series over time.

Figure A2: UK Problem Status Measures Over Time
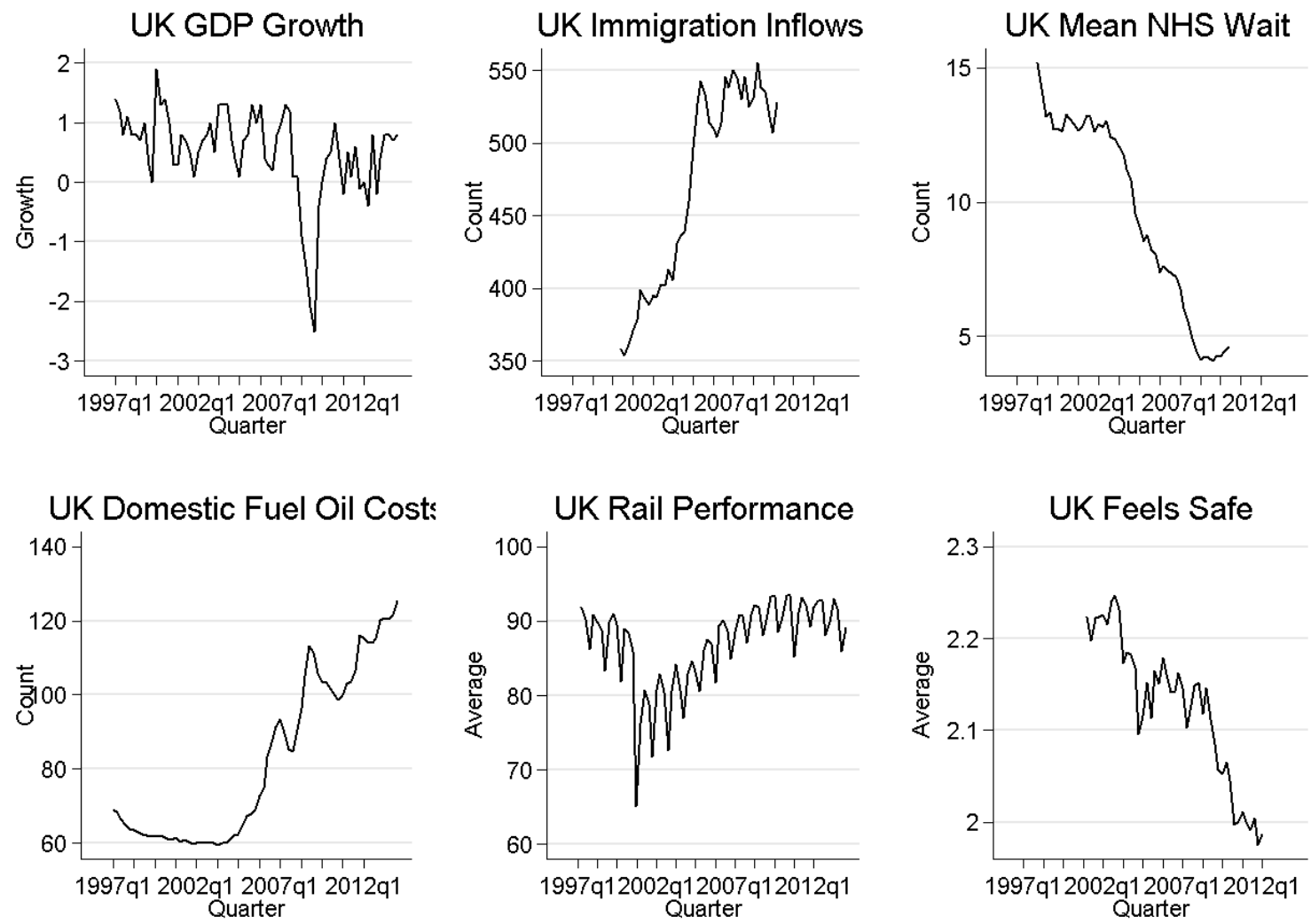
ONLINE APPENDIX B: US Results Including Divided House

Table B1: The Effects of Public Priorities and Problem Status on Congressional Hearings

\begin{tabular}{|c|c|c|c|c|}
\hline & Economy & Health & Energy & Transport \\
\hline Hearingst-1 & $\begin{array}{c}-0.76 \\
(0.07)^{* * *}\end{array}$ & $\begin{array}{l}-0.73 \\
(0.07)^{* * *}\end{array}$ & $\begin{array}{l}-0.67 \\
(0.07)^{* * * *}\end{array}$ & $\begin{array}{l}-1.02 \\
(0.10)^{* * *}\end{array}$ \\
\hline$\Delta \mathrm{MIP}_{\mathrm{t}}$ & $\begin{array}{l}4.19 \\
(2.67)\end{array}$ & $\begin{array}{r}0.75 \\
(12.11)\end{array}$ & $\begin{array}{l}44.69 \\
(7.14)^{* * *}\end{array}$ & \\
\hline $\mathrm{MIP}_{\mathrm{t}-1}$ & $\begin{array}{c}6.27 \\
(1.27)^{* * *}\end{array}$ & $\begin{array}{r}7.04 \\
(7.04)\end{array}$ & $\begin{array}{l}33.85 \\
(6.88)^{* * *}\end{array}$ & \\
\hline$\Delta$ Growth $_{\mathrm{t}}$ & $\begin{array}{r}-14.53 \\
(8.48)\end{array}$ & & & \\
\hline Growth $_{\mathrm{t}-1}$ & $\begin{array}{r}-10.67 \\
(15.94)\end{array}$ & & & \\
\hline$\Delta$ Medical $_{t}$ & & $\begin{array}{c}2.10 \\
(0.61)^{* * * *}\end{array}$ & & \\
\hline Medical $_{t-1}$ & & $\begin{array}{c}-0.04 \\
(0.07)\end{array}$ & & \\
\hline$\Delta$ Fuel $_{t}$ & & & $\begin{array}{l}0.04 \\
(0.02)^{*}\end{array}$ & \\
\hline Fuel $_{t-1}$ & & & $\begin{array}{l}0.02 \\
(0.01)^{* *}\end{array}$ & \\
\hline$\Delta \mathrm{Gas}_{\mathrm{t}}$ & & & & $\begin{array}{l}3.58 \\
(1.78)^{*}\end{array}$ \\
\hline Gast -1 & & & & $\begin{array}{c}2.32 \\
(0.66)^{* * * *}\end{array}$ \\
\hline$\Delta$ Divided $_{t}$ & $\begin{array}{c}2.53 \\
(0.92)^{* *}\end{array}$ & $\begin{array}{r}0.68 \\
(1.65)\end{array}$ & $\begin{array}{r}-1.27 \\
(1.25)\end{array}$ & $\begin{array}{r}2.39 \\
(1.67)\end{array}$ \\
\hline Divided $_{t-1}$ & $\begin{array}{l}-0.64 \\
(0.40)\end{array}$ & $\begin{array}{c}1.13 \\
(0.72)\end{array}$ & $\begin{array}{c}0.22 \\
(0.55)\end{array}$ & $\begin{array}{l}-0.67 \\
(0.78)\end{array}$ \\
\hline Trend & $\begin{array}{c}0.03 \\
(0.01)^{* *}\end{array}$ & $\begin{array}{c}0.09 \\
(0.02)^{* * *}\end{array}$ & $\begin{array}{c}0.09 \\
(0.02)^{* * *}\end{array}$ & \\
\hline Trend $^{2}$ & $\begin{array}{l}-0.00 \\
(0.00)^{*}\end{array}$ & $\begin{array}{r}-0.00 \\
(0.00)\end{array}$ & $\begin{array}{l}-0.00 \\
(0.00) * * *\end{array}$ & \\
\hline $2^{\text {nd }}$ Quarter & $\begin{array}{l}-0.06 \\
(0.33)\end{array}$ & $\begin{array}{c}4.80 \\
(0.57)^{* * * *}\end{array}$ & $\begin{array}{c}2.62 \\
(0.42)^{* * *}\end{array}$ & $\begin{array}{l}2.22 \\
(0.64)^{* *}\end{array}$ \\
\hline $3^{\text {rd }}$ Quarter & $\begin{array}{l}-0.42 \\
(0.38)\end{array}$ & $\begin{array}{c}4.06 \\
(0.69)^{* * * *}\end{array}$ & $\begin{array}{l}2.08 \\
(0.50)^{* * * *}\end{array}$ & $\begin{array}{l}2.21 \\
(0.77)^{* *}\end{array}$ \\
\hline $4^{\text {th }}$ Quarter & $\begin{array}{c}-1.61 \\
(0.32)^{* * *}\end{array}$ & $\begin{array}{c}0.27 \\
(0.62)\end{array}$ & $\begin{array}{r}-0.30 \\
(0.45)\end{array}$ & $\begin{array}{l}-0.46 \\
(0.66)\end{array}$ \\
\hline Constant & $\begin{array}{l}-0.47 \\
(0.48)\end{array}$ & $\begin{array}{r}-0.90 \\
(1.47)\end{array}$ & $\begin{array}{r}-1.04 \\
(0.63)\end{array}$ & $\begin{array}{c}5.76 \\
(1.16)^{* * * *}\end{array}$ \\
\hline$R^{2}$ & 0.53 & 0.59 & 0.57 & 0.64 \\
\hline$N$ & 216 & 216 & 217 & 110 \\
\hline
\end{tabular}

$* p<0.05 ; * * p<0.01 ; * * * p<0.001$ 
To investigate the potential effects for divided government, we include a control variable that is coded as 1 if the President is from a different party than the House of Representatives majority (and zero otherwise). The only issue on which divided government has a statistical significant effect is the economy. In this issue area, it appears that under divided government the number of hearings increases. The consequence of including divided government for this issue is that the short-run effect of problem status goes from being significance at 0.05 to being significance at 0.1 .

Table B2: Long Run Effects of Public Priorities and Problem Status on Congressional Hearings

\begin{tabular}{lllll}
\hline & Economy & Health & Energy & Transport \\
\hline LR MIP & 8.31 & 9.60 & 50.28 & NA \\
& $(1.53)^{* * *}$ & $(9.58)$ & $(9.05)^{* * *}$ & \\
LR Problem & -14.13 & -0.049 & 0.035 & 2.37 \\
& $(21.01)$ & $(0.094)$ & $(0.012)^{* *}$ & $(0.53)^{* * * *}$ \\
\hline
\end{tabular}

